$1-1-2009$

\title{
Christians in early and classical Sunni law
}

David M. Freidenreich

Colby College,dfreiden@colby.edu

Follow this and additional works at: https://digitalcommons.colby.edu/faculty_scholarship

Part of the Religion Commons

\section{Recommended Citation}

Freidenreich, David M., "Christians in early and classical Sunni law" (2009). Faculty Scholarship. 20. https://digitalcommons.colby.edu/faculty_scholarship/20 


\title{
Christians in early and classical Sunnī law
}

\author{
David M. Freidenreich
}

Islamic law devotes considerable attention to regulations related to Christians, who comprised a significant minority population within the medieval Islamic Near East. Such regulations appear in numerous areas of law, and every compendium or treatise that addresses one or more of these areas is likely to address Christians. Comprehensive documentation of references to Christians in Islamic legal literature, of the sort attempted in the preceding essay on Muslims in canon law, is therefore practically impossible. Such an endeavor is also of questionable utility because different law books often cover the same ground in very similar ways. The present essay seeks instead to sketch Sunnī laws relating to Christians in broad strokes and to direct readers to relevant secondary scholarship for further details and for citations of the most important primary sources. Shīi laws regarding Christians differ in significant ways from their Sunnī counterparts and therefore merit separate treatment. ${ }^{1}$

The place of Christians and other non-Muslims in Islamic (primarily Sunnī) law has received considerable attention within academic scholarship. Antoine Fattal's Le statut légal des non-Musulmans en pays d'Islam, a general survey, retains its value as an entry point into the study of this subject. It has been supplemented and often surpassed by a variety of more focused studies, of which Yohanan Friedmann's Tolerance and coercion in Islam deserves particular mention. A number of works, including Fattal's and especially Mark R. Cohen's Under crescent and cross, devote considerable attention to comparing medieval Islamic laws governing non-Muslims with their counterparts in Roman, Sasanid, and Christian sources. Placed in this context rather than viewed against the backdrop of twenty-first-century Western norms, the laws expressed in medieval Islamic sources appear commonplace and even relatively benign; non-Muslims subject to these laws, of course, surely did not see them as such. ${ }^{2}$

${ }^{1}$ Essays surveying classical Shîî law and departures from classical approaches to Christians among Sunnī and Shīī authorities appear in later volumes.

${ }^{2}$ A. Fattal, Le statut légal des non-Musulmans en pays d'islam, Beirut, 1958; 
The literature on minorities in Islamic law, although strong in many other respects, generally neglects to consider change over time in regulations regarding non-Muslims. This tendency, which the present essay makes no attempt to rectify, is due in part to the significant challenges associated with efforts to date legal works and normative statements ascribed to what scholars call the 'early' or formative period of Islamic law, roughly the first three Islamic centuries.

The onset of the 'classical' period of Sunni law, which extends beyond the year 1500, occurs in the tenth Christian century with the crystallization of four schools of Sunnì legal thought named after and oriented toward the teachings of eighth- or ninth-century 'founders'. The differences between these schools with respect to numerous aspects of jurisprudential theory and legal substance result in sometimes significant differences in their respective laws regarding Christians, differences that medieval and modern scholars alike duly note and discuss. In most cases, the authors of legal compendia and treatises were private citizens rather than government functionaries. These works, therefore, express normative ideals that did not necessarily receive support from the coercive powers of the state. Indeed, as an essay in a later volume discusses, Muslim political authorities at times treated their Christian subjects in ways that contravened the norms articulated in classical legal sources, sometimes to the benefit of these subjects and sometimes to their detriment.

Y. Friedmann, Tolerance and coercion in Islam. Interfaith relations in the Muslim tradition, Cambridge, 2003; M.R. Cohen, Under crescent and cross. The Jews in the Middle Ages, Princeton NJ, 1994, esp. pp. 52-74. Much of Cohen's discussion of Jews in the Islamic world applies to Christians as well.

Scholars and others concerned about the contemporary rise of radical political Islamic movements have written numerous works on the treatment of non-Muslims within Islamic law. Representative of this genre, in its title and contributors, is R. Spencer (ed.), The myth of Islamic tolerance. How Islamic law treats non-Muslims, Amherst NY, 2005; Bat Yeor, Mark Durie, Ibn Warraq, David G. Littman, Daniel Pipes, and Robert Spencer each wrote multiple essays in this volume. Works by advocates of political Islam paint a much more sympathetic picture of Islamic laws regarding non-Muslims; see, for example, M.S. Chaudhry, Non-Muslim minorities in an Islamic state, Lahore, 1995. Neither camp offers a sufficiently nuanced portrait of this subject matter, and for this reason the present essay steers clear of both. For a valuable analysis of the historiography of minorities (principally Jews) in the Islamic world, see Cohen, Under crescent and cross, pp. 3-14. 
The present essay highlights the manner in which Sunni authorities classify Christians. ${ }^{3}$ Most laws treat Christians as non-Muslims, no different from Jews, Zoroastrians, Hindus, and other 'dhimmis', the term for religious minorities to which we will return. Some treat Christians as 'Scripturists' ('People of the Book'), adherents of a religion based on a divinely revealed scripture; as such, Christians are classified alongside Jews and Muslims. ${ }^{4}$ This distribution pattern encapsulates the place of Christians within the worldview of Sunni jurists: Christians are inferior to Muslims yet they, along with Jews, merit a limited degree of parity with Muslims. Hardly any laws treat Christians in a class alone, and those that do make clear that the authors of early and classical Sunnī legal literature generally perceive Christianity as posing nothing more than a theoretical challenge for Muslims. In the wake of European Christian military conquests, especially in the Iberian peninsula, some Muslim authorities developed a more defensive posture regarding Christians than is manifest in classical texts; an essay in a later volume addresses this development.

\section{Christians as dhimmīs}

A sizeable majority of Islamic law regarding Christians treats the latter as dhimmis - more formally, ahl al-dhimma, 'people subject to a guarantee of protection. This term applies solely to non-Muslims living in lands governed by Muslims who accept the authority of their Muslim overlords; it thus excludes both rebellious non-Muslims and non-Muslims who live outside the Islamic world, including those who reside temporarily in Muslim lands for trade or other purposes. ${ }^{5}$ Some

${ }^{3}$ On the classification of non-Muslims, see also Y. Friedmann, 'Classification of unbelievers in Sunnī Muslim law and tradition', JSAI 22 (1998) 163-95, revised and expanded in his Tolerance and coercion, pp. 54-86.

4 The familiar term 'People of the Book' is a literal trans. of the Arabic phrase ahl $a l-k i t a \bar{b}$. Most legal sources employ the term kitābi, which refers to an individual member of one of these peoples. For ease of reference, I translate kitābi as 'Scripturist'. To my knowledge, this term was coined by N. Robinson; Friedmann, in contrast, employs the tongue-twisting term 'Scriptuary', perhaps inspired by the French 'Scripturaire' used by Fattal.

${ }^{5}$ No legal protection is granted to rebellious non-Muslims, such as those who support foreign invaders, or to non-Muslims resident in the territory of foreign enemies. A handful of laws address non-Muslim visitors to Muslim lands and nonMuslims who reside in foreign domains with which Muslims have negotiated an armistice. Other laws address the status of Muslims who dwell outside the Islamic world 
jurists limit the protection associated with dhimmī status to Jews and Christians; others extend that protection to most or virtually all other non-Muslims as well. ${ }^{6}$ Conversion to Islam frees the convert from the obligations incumbent upon dhimmis, and jurists often seek to insure that the act of conversion redounds to the convert's advantage.

Islamic law obligates Muslim authorities to abstain from acts of hostility toward dhimmis, to accord them various rights, and to protect them from attack by Muslims or foreigners. It further grants to dhimmis, including the slaves and wives of Muslim masters, the right to freely exercise their religion in private. Dhimmīs, in turn, must acknowledge their subservience to Muslim authorities and adhere to Islamic laws governing dhimmīs. Non-Muslims who refuse to accept these terms or who renege on their commitments forfeit the right to live as non-Muslims in the lands of Islam. Enforcement of dhimmi obligations was generally entrusted to the muhtasib, the government official responsible for ensuring public morality. ${ }^{8}$

Chief among the obligations incumbent upon dhimmis is payment of the jizya, a qurānic obligation which Muslim jurists classically understand to refer to an annual poll tax imposed solely upon nonMuslims. ${ }^{9}$ Jurists offer two distinct interpretations of the jizya, each of

or enter foreign lands temporarily for the purpose of trade; on this subject, discussed in greater detail in an essay in a later volume, see K. Abou el Fadl, 'Islamic law and Muslim minorities. The juristic discourse on Muslim minorities from the second/eighth to the eleventh/seventeenth centuries', Islamic Law and Society 1 (1994) 141-87.

${ }^{6}$ On the legal conception of 'dhimmitude', to use the term coined by Bat Yeor, see Fattal, Statut légal, pp. 71-84. On the category of ahl al-dhimma and its scope, see Friedmann, Tolerance and coercion, pp. 54-55, 58-69, 72-83; Fattal, Statut légal, pp. 160-63; see also Y. Friedmann, 'The temple of Multān. A note on early Muslim attitudes to idolatry', Israel Oriental Studies 2 (1972) 176-82.

7 Some of the ramifications of this right are explored by Friedmann, Tolerance and coercion, pp. 187-90; R. Marston Speight, 'The place of Christians in ninth-century North Africa, according to Muslim sources', Islamochristiana 4 (1978) 47-65, pp. 53, 59. The latter essay surveys references to non-Muslims in the Mudawwana, the foundational compendium of Mālikī law ascribed to Sahnūn (d. 854).

${ }^{8}$ See A. García-Sanjuán, 'Jews and Christians in Almoravid Seville as portrayed by the Islamic jurist Ibn 'Abdūn', Medieval Encounters 14 (2008) 78-98; G. Weigert, 'A note on the muhtasib and ahl al-dhimma', Der Islam 75 (1998) 331-37. García-Sanjuán translates and analyses the relevant extracts from Ibn 'Abdūn's manual for the muhtasib; relevant extracts from other Andalusian works of this genre appear in C. Melville and A. Ubaydli, Christians and Moors in Spain. Vol. 3, Arabic sources (711-1501), Warminster, 1992, pp. 112-15.

${ }_{9}$ Q 9:29. The original meaning of this verse has been subject to considerable scholarly debate, whose major players include M.M. Bravmann, C. Cahen, M.J. Kister, 
which accounts for different details in the laws governing its payment. On the one hand, this tax constitutes a fee for services rendered to dhimmis by Muslims: the right to live as non-Muslims in Islamic territories, exemption from military service, and the protection provided by Muslim soldiers. For this reason, jurists generally exempt women, minors, slaves, and the infirm from the jizya payment, as Muslims in these categories are exempt from military service. (Authorities differ over whether and to what degree the tax applies to indigent dhimmis. ${ }^{10}$ On the other hand, the jizya constitutes a penalty imposed upon nonMuslims on account of their refusal to embrace Islam. This notion underlies the widespread norm of exacting payment of the jizya in humiliating circumstances. ${ }^{11}$ Dhimmis are also required to pay distinctive property taxes and to pay taxes on commercial transactions at a higher rate than Muslims. ${ }^{12}$

The inferiority of dhimmis to their Muslim overlords exemplified in the humiliation associated with payment of the jizya is reinforced

and U. Rubin. Ibn Warraq (ed.), What the Koran really says: Language, text, and commentary, Amherst NY, 2002, pp. 343-86, helpfully anthologizes (and, where necessary, translates from the French original) the relevant essays and notes on this subject, which first appeared in Arabica 9, 10, 11, 13 and 14, and Der Islam 70.

${ }_{10}$ In addition to the primary references cited in the following note, see E. Alschech, 'Islamic law, practice, and legal doctrine. Exempting the poor from the jizya under the Ayyubids (1171-1250)', Islamic Law and Society 10 (2003) 348-75.

${ }^{11}$ On the jizya: Cohen, Under crescent and cross, pp. 56, 68-72; Fattal, Statut légal, pp. 264-91. See also Speight, 'Place of Christians', pp. 54-55, and the references in the following note. On the humiliating nature of this tax as administered in seventh- and eighth-century Syria and Iraq, see also C.F. Robinson, 'Neck-sealing in early Islam, Journal of the Economic and Social History of the Orient 48 (2005) 401-41. The Banu Taghlib, an Arab Christian tribe, reportedly objected to payment of the jizya precisely because of the humiliation involved in its payment, humiliation which the tribesmen felt ought not to be imposed upon Arabs; see n. 43.

${ }^{12}$ Fattal, Statut légal, pp. 292-313. On tax administration in general and taxes imposed upon non-Muslims in particular, see M.G. Morony, Iraq after the Muslim conquest, Princeton NJ, 1984, pp. 99-124. The Kitāb al-kharāj of Ya'qūb Abū Yūsuf (d. 798), an early treatise on Islamic tax law by one of the 'founders' of the Hanafi school of jurisprudence, contains several chapters regarding the taxation and treatment of dhimmis and exists in a variety of modern editions and translations; see the entry 'Abū Yūsuf' in this volume. Relevant extracts from the Kitāb al-kharāj appear in N. Stillman, The Jews of Arab lands. A history and source book, Philadelphia PA, 1979, pp. 159-61; for another source that recounts the manner in which jizya was paid during the thirteenth century, see p. 18o. A different extract from the Kitāb al-kharāj and other relevant sources on the status of non-Muslims appear in B. Lewis (ed.), Islam from the Prophet Muhammad to the capture of Constantinople, 2 vols, New York, 1974, ii (Religion and society), pp. 217-35. 
through a variety of laws. Many of these appear in the so-called 'Pact of 'Umar', which purports to be a set of surrender terms proposed by Christians to the second Caliph, 'Umar ibn al-Khaț̣āb (r. 634-44); jurists ultimately applied the terms in this pact to all dhimmis, overriding local capitulation agreements. Scholars dismiss the association of this pact with 'Umar but find in its contents and form elements that reflect eighth- and ninth-century historical realities, including extant capitulation treaties and common caliphal administrative practices. ${ }^{13}$ Among the terms of the Pact of 'Umar, Christians obligate themselves to show deference to Muslims by rising when Muslims wish to sit and refraining from building homes higher than those of Muslims. Christians must provide hospitality to traveling Muslims, may not shelter foreign spies, and may not strike Muslims, nor may they purchase slaves whose service ought to benefit Muslims. ${ }^{14}$ Christians further agree not to ride horses or to bear arms, both symbols of elevated social status, and commit themselves to wear their traditional clothing and not to adopt Muslim styles of dress, honorific titles, or Arabic signets; these practices, which may have originally been meant to preserve the distinction between Muslims and the majority population, ultimately became signs of humiliation as well. ${ }^{15}$

${ }^{13}$ See the entry 'Pact of 'Umar' in this volume, and the references cited there. Milka Levy-Rubin, author of this entry, elsewhere challenges scholarly consensus by arguing that the restrictions found in the Pact of 'Umar were in fact regularly and effectively enforced by medieval Muslim rulers; see M. Levy-Rubin, 'From early harbingers of shurūt 'Umar to its systematic enforcement', in Border crossings. Interreligious interaction and the exchange of ideas in the Islamic Middle Ages, ed. D.M. Freidenreich and M. Goldstein, Philadelphia (forthcoming), and also her forthcoming book on this subject. On the supersession of local treaties, see also H.E. Kassis, 'Some aspects of the legal position of Christians under Mālikī jurisprudence in al-Andalus', Pd'O 24 (1999) pp. 114-16.

${ }^{14}$ On the last of these restrictions, see Cohen, Under crescent and cross, pp. 64-65.

${ }_{15}$ On regulations governing the clothing worn by Christians, see Cohen, Under crescent and cross, pp. 62-64; Fattal, Statut légal, pp. 96-112; I. Lichtenstadter, 'The distinctive dress of non-Muslims in Islamic countries', Historia Judaica 5 (1943) 35-52; A.S. Tritton, The caliphs and their non-Muslim subjects. A critical study of the Covenant of 'Umar, London, 1930, 1970², pp. 115-26. On both clothing restrictions and the right to ride animals, see also E. Ashtor, 'The social isolation of ahl adh-dhimma', in Pal Hirschler memorial book, Budapest, 1949, 74-85 (repr. in The medieval Near East. Social and economic history, London, 1978). Restrictions governing the clothing and riding practices of non-Muslims appear consistently in medieval accounts of an edict promulgated by the Caliph 'Umar ibn 'Abd al-'Aziz, with whom some scholars associate the Pact of 'Umar itself; see Levy-Rubin, 'From early harbingers', and Levy-Rubin's forthcoming book. On the question of why Christians would commit themselves to 
Various legal sources also prohibit Muslims themselves from adopting the mannerisms of non-Muslims, especially in matters of dress and ritual, and instruct Muslims to refrain from greeting non-Muslims in the same manner that they greet fellow believers. ${ }^{16}$ Jurists from Andalusia express particular concern about the differentiation of Muslims and Christians. ${ }^{17}$ This elevated concern is often manifest in differences of opinion between members of the Mālikī school of jurisprudence, dominant in Andalusia and North Africa, and jurists affiliated with other Sunnī schools.

Laws regarding dhimmīs exemplify the dictum, 'Islam is superior and cannot be superceded. ${ }^{18}$ For this reason, Islamic law prohibits dhimmis from serving in positions of authority over Muslims, whether as public officials, members of the military, or owners of Muslim slaves; the law also restricts commercial interactions in which a Muslim might become inferior to a dhimmi ${ }^{19}$ According to one authority,

seemingly humiliating restrictions, see M.R. Cohen, 'What was the Pact of 'Umar? A literary-historical study', JSAI 23 (1999) 100-57, pp. 129-30, and, with particular attention to matters of dress, A. Noth, 'Abgrenzungsprobleme zwischen Muslimen und NichtMuslimen. Die "Bedingungen 'Umars (â̂-Ŝrūṭ al-'Umariyya)" unter einem anderen Aspekt gelesen', JSAI 9 (1987) 290-315 (trans. M. Muelhaeusler, 'Problems of differentiation between Muslims and non-Muslims. Re-reading the "Ordinances of 'Umar (al-shurūt al-'Umariyya)", in R. Hoyland (ed.), Muslims and others in early Islamic society, Aldershot, 2004, 103-24.

${ }^{16}$ See M.J. Kister, “'Do not assimilate yourselves...”: lā tashabbahü, JSAI 12 (1989) 321-71 (repr. in Hoyland, Muslims and others). Kister emphasizes that these prohibitions originated in the early period of Islamic law. It is noteworthy that most of the prohibitions Kister adduces address practices associated with Judaism or preIslamic Arabian religion and only a small number relate specifically to Christian practices. On the proper greetings to offer non-Muslims and proper interaction with one's non-Muslim neighbor, see also Cohen, Under crescent and cross, pp. 131-32; H.E. Kassis, 'Arabic-speaking Christians in al-Andalus in an age of turmoil (fifth/ eleventh century until AH 478/AD 1085)', Al-Qanțara 15 (1994) 401-50, pp. 405-7.

${ }_{17}$ See J.M. Safran, 'Identity and differentiation in ninth-century al-Andalus', Speculum 76 (2001) 573-98; see also García-Sanjuán, 'Jews and Christians'; Kassis, 'Legal position of Christians'.

${ }^{18}$ Șahịh al-Bukhārī (Vaduz, Liechtenstein: Jam iyyat al-Makniz al-Islāmī, 200o), 23.79. This hadith is adduced by Friedmann, Tolerance and coercion, p. 35, and A. Fattal, 'How dhimmīs were judged in the Islamic world', in Hoyland, Muslims and others, p. 89, both of whom cite the tradition as appearing in 23.80 . (The latter essay is a trans. by S. Pickford, of 'Comment les dhimmis étaient jugés en terre d'islam', Cahiers d'Histoire Egyptienne 3 (1951) 321-41.)

19 The prohibition against dhimmīs in public office, rooted in numerous qur'ānic verses and hadiths, was often ignored by rulers in the interest of expediency. Jurists differ over the legitimacy of employing dhimmins in the military. See Friedmann, 
Muslims ought not to perform menial labor on behalf of dhimmīs or allow themselves to be treated by non-Muslim physicians. ${ }^{20}$

The principle that Muslims should not be subject to the authority of non-Muslims underlies a number of inequities in the administration of justice in Islamic law. Legal proceedings involving a Muslim and a dhimmi must be held in an Islamic court, although dhimmis are entitled to turn to their own judicial authorities for internal matters. ${ }^{21}$ When the accused is a Muslim, dhimmis are not allowed to offer testimony against him; some jurists reject the legitimacy of testimony by dhimmis in all circumstances on the grounds that non-Muslims are presumed to be untrustworthy as witnesses. ${ }^{22}$ Some jurists value the worth of Muslims and non-Muslims differently for the purpose of assessing penalties in cases of murder or bodily injury; others assert that payment of the jizya entitles dhimmis to equal treatment under the law in this respect. ${ }^{23}$ Islamic law denies dhimmis the right to inherit from relatives who converted to Islam; authorities differ over whether Muslims are entitled to inherit from non-Muslim relatives and whether dhimmis of different confessions may inherit one from another. ${ }^{24}$

Islamic law seeks to create a society that makes manifest the supremacy of Islam, and to this end it curtails the public display of nonMuslim religious life even as it allows non-Muslims to practice their own religions. Several of the terms of the Pact of 'Umar relate specifically to religious matters. Chief among these is the rule that Christians may not build new churches, monasteries, or other religious buildings, and that they may not restore any such buildings that fall into

Tolerance and coercion, pp. 36-37; Cohen, Under crescent and cross, pp. 65-68; Fattal, Statut légal, pp. 232-63; see also Tritton, Caliphs and their non-Muslim subjects, pp. 18-36. On commercial interactions between Muslims and non-Muslims, see Fattal, Statut légal, pp. 144-50; Speight, 'Place of Christians', pp. 59-60.

${ }^{20}$ García-Sanjuán, 'Jews and Christians', pp. 84-86.

${ }^{21}$ Islamic law also governs cases involving dhimmīs of different confessions and cases in which the parties choose to turn to a Muslim judge. See Fattal, 'How dhimmīs were judged'; see also Speight, 'Place of Christians', pp. 61-62.

${ }_{22}$ Friedmann, Tolerance and coercion, pp. 35-36; Fattal, 'How dhimmīs were judged', pp. 98-102; Speight, 'Place of Christians', pp. 6o-61.

${ }_{23}$ Friedmann, Tolerance and coercion, pp. 39-53; Fattal, Statut légal, pp. 113-18; see also Speight, 'Place of Christians', pp. 6o-61. One example of differential penalties is referred to below in n. 36 .

${ }^{24}$ Friedmann, Tolerance and coercion, pp. 55-58; Fattal, Statut légal, pp. 137-42; see also Speight, 'Place of Christians', pp. 55-56. On the rights of dhimmis to establish endowments, see Fattal, Statut légal, p. 143. 
ruin or are located in Muslim neighborhoods. This rule, however, was not regularly enforced, and jurists developed a variety of exceptions and qualifications to it. ${ }^{25}$ Christians agree not to proselytize and not to prevent Christians from converting to Islam. The Pact of 'Umar also obligates Christians to refrain from holding public religious ceremonies and displaying religious symbols publicly, to beat the wooden clappers of their churches (the local equivalent of church bells) very quietly, not to raise their voices when praying, and to direct their funeral processions away from Muslim populations. ${ }^{26}$ These regulations collectively serve to minimize the visible 'footprint' of Christianity within the Islamic world. Sunnī authorities, however, generally do not impose distinctively Islamic norms on dhimmis. Thus, for example, Christians may not sell wine among Muslims but they may purchase, possess, and consume it themselves, even when married to Muslim husbands; ${ }^{27}$ similarly, dhimmis may engage in interest-generating commercial activities among themselves. Violating Islamic norms of blasphemy, however, nullifies the terms of the dhimma and merits capital punishment. ${ }^{28}$

Because of Islam's supremacy over all religions, including those previously revealed by God, conversion from Islam to Christianity or any other religion is strictly forbidden, as is Muslim participation in Christian festivals. ${ }^{29}$ Whereas born Christians are eligible for dhimmi

${ }^{25}$ Kassis, 'Legal position of Christians', pp. 118-25; Cohen, Under crescent and cross, pp. 58-60; Fattal, Statut légal, pp. 174-203; see also Tritton, Caliphs and their nonMuslim subjects, pp. 37-77. On legal attitudes towards the presence of non-Muslim residents and their religious institutions in Muslim neighborhoods, see M. LevyRubin, 'Shurūt 'Umar and its alternatives. The legal debate on the status of the dhimmīs', JSAI 30 (2005) 170-206; Ashtor, 'Social isolation', pp. 85-88.

${ }^{26}$ Fattal, Statut légal, pp. 203-11; see also Tritton, Caliphs and their non-Muslim subjects, pp. 100-14.

${ }_{27}$ On this and other regulations guaranteeing non-Muslim wives freedom of religion, see Friedmann, Tolerance and coercion, pp. 188-9o; S.A. Spectorsky, 'Women of the People of the Book. Intermarriage in early figh texts', in B.H. Hary, J.L. Hayes and F. Astren (eds), Judaism and Islam: Boundaries, communication and interaction. Essays in honor of William M. Brinner, Leiden, 2000, 269-78, p. 274. Some authorities, however, prohibit all dhimmis from possessing or consuming wine; see Levy-Rubin, 'From early harbingers'.

${ }_{28}$ See Safran, 'Identity and differentiation', pp. 588-97; A. Turki, 'Situation du "tributaire" qui insulte l'islam, au regard de la doctrine et de la jurisprudence musulmanes', Studia Islamica 30 (1969) 39-72; Fattal, Statut légal, pp. 122-24.

${ }_{29}$ Concern about participation in Christian festivals is especially prevalent in Andalusian and North African sources. See Safran, 'Identity and differentiation', p. 581; 
status, converts to Christianity from Islam are ineligible for this status and are therefore liable to the death penalty if they refuse to re-embrace Islam. Some authorities similarly forbid conversion from one nonMuslim religion to another on the grounds that one may not choose any religion over Islam. Forced conversion of non-Muslims is generally forbidden, and some jurists therefore allow non-Muslims who converted out of duress to return to their original religion. Jurists do, however, condone the compulsory conversion of non-Muslim women, minors, and prisoners of war in various circumstances..$^{30}$ Islamic law defines the offspring of marriages between Muslim men and Christian women as Muslims. Some jurists infer from this that the offspring of mixed marriages among dhimmis are to be affiliated to the religion of their father, but most affiliate such children to the superior of the parents' faiths; in the latter case, the child of a Zoroastrian father and Christian mother is a Christian..$^{31}$

Non-Muslims may not reside in the region of Mecca and Medina, in accordance with the last will of the Prophet; jurists differ over whether this prohibition extends to the entirety of the Arabian peninsula, and whether it applies to visitors. Many jurists specifically prohibit non-Muslims from entering the precincts of the Ka'ba in Mecca, and some extend this prohibition to all mosques. ${ }^{32}$ Proceeds from $z a k a \bar{t}$, the alms tax obligatory upon Muslims, may not be given to non-Muslims who would otherwise qualify for such aid, although Muslims are welcome to give other forms of charity to non-Muslims. ${ }^{33}$ Various authorities prohibit non-Muslims from possessing or studying the Qur'ān or other sacred Islamic texts, a prohibition sometimes associated with the assertion that non-Muslims are impure. ${ }^{34}$

R.M. Speight, 'Muslim attitudes toward Christians in the Maghrib during the Fațimid period, 297/909-358/969', in Y.Y. Haddad and W.Z. Haddad (eds), Christian-Muslim encounters, Gainesville FL, 1995, 180-92, pp. 185-86; H.E. Kassis, 'Muslim revival in Spain in the fifth/eleventh century: Causes and ramifications', Der Islam 67 (1990) 78-110, pp. 85-86.

${ }^{30}$ Friedmann, Tolerance and coercion, pp. 106-59; Safran, 'Identity and differentiation', pp. 585-88; Fattal, Statut légal, pp. 163-69.

${ }^{31}$ Friedmann, Tolerance and coercion, pp. 174-75; Speight, 'Place of Christians', pp. 58-59. On the status of children when one parent converts to Islam, see M. Shatzmiller, 'Marriage, family, and the faith: Women's conversion to Islam', Journal of Family History 21 (1996) 235-66, pp. 247-48.

${ }^{32}$ Fattal, Statut légal, pp. 85-93.

${ }_{33}$ Speight, 'Place of Christians', p. 57.

${ }^{34}$ Fattal, Statut légal, pp. 144, 148-49, 159. Some jurists also express concern about 
Islamic legal literature tends to regard non-Muslims as impure, but jurists vigorously debate the reason for this status and its implications for Muslim-dhimmī interactions. Sunnīs generally hold that nonMuslims are impure by virtue of their failure to perform the purification rituals necessary to restore the state of purity that is disrupted by any number of normal events. These jurists also speak of the beliefs of non-Muslims as 'impure' in a metaphorical sense. Some Sunnīs, however, hold that non-Muslims are intrinsically, and not merely circumstantially, impure on account of their beliefs. This minority opinion is especially prominent among jurists from Andalusia and North Africa, who tend to refer specifically to the impurity of Christians; scholars have suggested that social factors distinctive to the region may underlie this position. Even these jurists, however, do not regard the impurity of non-Muslims as grounds for stringent measures separating Muslims from non-Muslims of the sort that ultimately developed in some Shīi ircles; Muslims who come into contact with non-Muslims in a state of impurity are simply enjoined to perform the necessary act of ablution before engaging in ritual activity. ${ }^{35}$ Consequently, the notion that non-Muslims are impure does not interfere with Sunnī laws that permit certain forms of intimacy between Muslims and People of the Book, permissions associated with the fact that Christians and Jews adhere to divinely revealed Scriptures.

\section{Christians as Scripturists}

Islamic laws that treat Christians as dhimmins tend to impose rules and restrictions on the activity of non-Muslims. Laws that treat Christians as Scripturists, in contrast, are primarily reflexive in nature: they regulate what Muslims themselves may or may not do in matters that

Christians teaching either the Qur'ān or prior revelations to Muslims; see Speight, 'Muslim attitudes', p. 185. On the impurity of non-Muslims, see the references in the following note.

35 Z. Maghen, 'Strangers and brothers. The ritual status of unbelievers in Islamic jurisprudence', Medieval Encounters 12 (2006) 173-223; J.M. Safran, 'Rules of purity and confessional boundaries. Māliki debates about the pollution of the Christian', History of Religions 42 (2003) 197-212; M.H. Katz, Body of text. The emergence of the Sunni law of ritual purity, Albany NY, 2002, pp. 157-67; see also Safran, 'Identity and differentiation', pp. 581-83. On Shîi conceptions of non-Muslim impurity and its implications, see Maghen's essay and the essay on Christians in early and classical Shî̄î law in a later volume. 
relate to non-Muslims. Laws that fall into this latter category may still profitably be labeled 'dhimmī law' - analogous to Christian 'Jewry law' and 'Saracen law' - as they presume the inferiority and subservience of the Christians (and Jews). ${ }^{36}$ These laws, however, emphasize the relatively elevated status of Christians and Jews among non-Muslims. Whereas the laws surveyed in the previous section express a binary distinction between Us and Them ( 1 and o), laws that treat Christians as Scripturists reveal that Muslim jurists embraced a more complex system for classifying foreigners, one in which Christians and Jews are, in mathematical terms, less than 1 but greater than 0.

This intermediate status is given numerical expression by some jurists in their discussion of the blood-money that is due in certain cases to the surviving relatives of a murder victim. According to jurists of the Māliki and Hanbali schools, the amount of the bloodmoney when the victim is a Christian or Jew is either 4,000 or 6,000 dirhams, whereas when the victim is a Zoroastrian or another type of non-Muslim the payment due is only 800 dirhams. (The blood-money for a Muslim victim is 12,00o dirhams.) Other jurists hold that the value of the blood-money is identical, regardless of the affiliation of the victim; one jurist, Ibn Hazm, holds on technical grounds that no blood-money is paid when the victim is a non-Muslim..$^{37}$

Most legal discussion of Christians as Scripturists stems from the qur̉ānic verse:

Permitted to you this day are the good things, and the food of those who were given the Book is permitted to you, and your food is permitted to them. So are the chaste women among the believers and the chaste women among those who were given the Book before you, provided you give them their dowries and take them in chastity, not in wantonness or as mistresses. If anyone denies the faith, his work shall be of no avail to him, and in the Hereafter he will be among the losers. (Q 5:5)

Sunnī interpreters and jurists uniformly understand the term 'food' (tacam) in this verse as referring to all foodstuffs that God has not prohibited, including permissible meat, the subject of the preceding

${ }^{36}$ On the terms 'imposed law', 'reflexive law', 'Jewry law', and 'Saracen law', see the companion essay on canon law in this volume, which observes that Christian Saracen law from ca. 650 to 1000, unlike Jewry law from the period, was exclusively reflexive in its nature.

${ }^{37}$ Friedmann, Tolerance and coercion, pp. 47-50. 
verses. Animal slaughter was regarded as a divinely prescribed ritual activity in Near Eastern antiquity. For this reason, the declaration that the slaughter practices of 'the believers' and the slaughter practices of 'those who were given the Book' are equally valid indicates that Christians and Jews, no less than Muslims themselves, act in accordance with authentic divine revelations. ${ }^{38}$ The meat of animals slaughtered by Zoroastrians, in contrast, is forbidden for consumption by Muslims. The permission of meat prepared by Scripturists expresses the affinity - indeed, the parity - of Jews, Christians, and Muslims. ${ }^{39}$

The limits to this parity, however, become apparent as Q 5:5 continues. 'Chaste women among those who were given the Book before you' are no less suitable for marriage than 'chaste women among the believers' because all come from communities committed to an authentic Scripture; idolatrous women, in contrast, are unfit marriage partners ( $\mathrm{Q}$ 2:221). Nevertheless, a Muslim woman may not marry a Christian or Jewish man because a Muslim wife may not be subservient to a non-Muslim husband..$^{40}$ Sunnī jurists, who regard such a union as a serious breach of the proper social order, prescribe severe punishments for dhimmis who transgress this norm, and they require married women who convert to Islam to separate from their non-Muslim husbands if the husbands do not follow suit. ${ }^{41} \mathrm{Q}$ 5:5 and the legal discussions that develop

${ }^{38}$ Some authorities, however, require that Christian butchers slaughter animals under Muslim supervision to ensure that the butchers do in fact follow divine dictates in this manner. In addition to the references cited in the following note, see Fattal, Statut légal, p. 97.

${ }^{39}$ See D.M. Freidenreich, Thou shalt not eat with them: Foreigners and their food in Jewish, Christian, and Islamic law, Berkeley CA, forthcoming, a revision of Foreign food. A comparatively-enriched analysis of Jewish, Christian, and Islamic law, New York, 2006 (Diss. Columbia University). See also N. Tsafrir, 'The attitude of Sunnī Islam toward Jews and Christians as reflected in some legal issues', Al-Qanțara 26 (2005) 317-28; M.K. Masud, 'Food and the notion of purity in the fatāwa literature', in M. Marín and D. Waines (eds), Alimentacion de las culturas Islamicas, Madrid, 1994, 89-110; Speight, 'Place of Christians', pp. 57-58. Masud focuses primarily on modern interpretations of early and classical opinions regarding Christian meat.

${ }^{40}$ Nor, according to many jurists, may a Muslim free man marry a non-Muslim slave woman: the incongruity in status between the superior man and the doubly inferior woman is too great. (Muslim men may marry Muslim slave women.) See the primary references cited in the following note.

${ }^{41}$ On laws governing interfaith marriage, see Friedmann, Tolerance and coercion, pp. 160-93; Spectorsky, 'Women of the People of the Book'; Shatzmiller, 'Marriage, family, and the faith'; see also Tsafrir, 'Attitude of Sunnī Islam', pp. 228-32; Speight, 'Place of Christians', pp. 58-59. On Mālikì disapproval of such marriages, even while 
around it strike a careful balance between the legitimation of Christianity and Judaism on the one hand and the affirmation of Islam's superiority on the other. The former principle, no less than the latter, is crucial to the self-definition of Islam that emerges from these texts: Islam stands in continuity with its predecessor religions even as it constitutes the culmination and climax of God's unfolding revelation.

The theological and definitional issues at stake in the permission of Christian meat and Christian wives become clear in legal discussions of borderline Christian communities. Some jurists limit the application of these permissions to dhimmis: only Christians who acknowledge the superiority of Islam may be granted a limited degree of parity with Muslims..$^{42}$ The Banū Taghlib, a large and powerful Arab Christian tribe at the time of the Arab conquest, attracts particular attention in the legal literature and becomes paradigmatic of Arab Christians in general. ${ }^{43}$ Most Sunnī authorities treat the Banū Taghlib as Christians even if they might be ignorant of their religion's tenets or latecomers to the faith. Some, however, express antipathy toward the Taghlibis and refuse to extend to them the permissive laws that apply to other Christians, apparently out of a sense that all Arabs ought to embrace the teachings of God's Messenger to the Arabs. Others limit these permissive laws to Christians whose ancestors converted to Christianity before the time of Muhammad. Pre-Islamic converts, after all, associated themselves with the best form of religion then in existence, but those who converted to Christianity after the time of Muhammad rejected their obligation to believe not only in

acknowledging their permissibility, see also Safran, 'Identity and differentiation', pp. 583-84.

${ }^{42}$ Freidenreich, Foreign food, p. 295. This position, advanced solely by jurists affiliated with the Mālikī school, constitutes another instance of a restrictive attitude toward Christians distinctive to Andalusian and North African legal sources. Similarly, Mālikīs express greater opposition to Muslim patronage of non-Muslim butchers and are the only Sunnī jurists who question the permissibility of wild animals killed by Christian hunters.

${ }_{43}$ On the Banū Taghlib, see M. Lecker, 'Tribes in pre- and early Islamic Arabia', in Lecker, People, tribes and society in Arabia around the time of Muhammad, Aldershot, 2005, XI, pp. 34-47. On the legal status of this and other groups of Arab Christians, see Friedmann, Tolerance and coercion, pp. 60-69; on payment of the jizya by Taghlibīs, see also Fattal, Statut légal, pp. 274-75. N. Tsafrir, Yahas ha-halakhah ha-muslemit kelapei datot aherot: 'Inyanei shehițah ve-nisu'in, Jerusalem, 1988 (MA diss. The Hebrew University), pp. 16-29, helpfully traces the history of normative traditions regarding Arab Christians in general and the Banū Taghlib in particular. 
God but also in his final Prophet. The Shāfíi jurist Yahyā ibn Sharaf al-Nawawi (d. 1277) draws a further distinction between those whose ancestors embraced Christianity before that religion was corrupted and those whose ancestors converted between the time of its corruption and the revelation of the Qur'ān. As Muslim jurists themselves did not know when Christianity became corrupted, this distinction is of no practical value and reflects the scholastic nature of much of the discussion regarding laws that treat Christians as Scripturists. These laws serve first and foremost to express Sunnī ideas regarding the relationship between Islam and its predecessor religions. ${ }^{44}$

The focus of Islamic legal discourse regarding Christians on issues of theoretical rather than practical relevance is also apparent in the only legal discussion known to this author that treats Christians not as dhimmis or Scripturists but rather as believers in the divinity of Christ. ${ }^{45}$ Islamic law requires Muslim butchers to invoke the name of God over the act of animal slaughter, and Muslim jurists presume that idolatrous butchers invoke the name of a being other than God. These jurists also discuss the status of meat prepared by a Christian butcher who invokes the name of Christ. As no Christian source indicates that Christian butchers actually engaged in this practice, it would seem that these discussions are scholastic in their orientation, designed to probe the degree to which Islam's legitimation of Christianity excuses Christians from the basic principles of Islamic monotheism. ${ }^{46}$

The debate regarding meat from animals slaughtered in the name of Christ is surprisingly vigorous, with prominent Sunni authorities lining up on both sides of the argument. Most jurists express serious reservations about the permissibility of such meat, but even those who prohibit its consumption are careful to preserve the permissibility in principle of meat prepared by Christians. The symbolic significance of this permission, embodying as it does the affinity between Islam and its predecessor traditions, is evidently of considerable

${ }_{44}$ Yaḥyā ibn Sharaf al-Nawawī Raw dat al-țālibīn, 5 vols, Beirut, 200o, v, pp. 474-75. See Freidenreich, Thou shalt not eat with them.

${ }^{45}$ On this subject, see Freidenreich, Thou shalt not eat with them; see also D.M. Freidenreich, 'Five questions about non-Muslim meat. Toward a new appreciation of Ibn Qayyim al-Ğawziyyah's contribution to Islamic law', Oriente Moderno (forthcoming); Tsafrir, 'Attitude of Sunnī Islam', pp. 323-28.

${ }_{46}$ Of more practical relevance are parallel discussions regarding meat prepared for Christian feast days; opinions regarding such meat tend to match those regarding the meat of animals slaughtered in the name of Christ. 
importance to Sunnī jurists. Muhammad ibn 'Abdallāh ibn al-'Arabī (d. 1148), who goes so far as to permit Muslim consumption of chickens which Christians slaughter in a manner that contravenes Islamic law, captures the logic that motivates Sunnī jurists to bend over backwards in their efforts to permit Christian meat: 'Greater respect is accorded to [Christians] than to idolaters because they adhere to God's Book and cling to the coat tails of prophets.' ${ }^{47}$ Even as they seek to ensure the absolute superiority of Islam and its adherents over all others, Sunni jurists are careful to express in limited ways the relatively elevated status of Christians and Jews as People of the Book.

47 Muhammad ibn 'Abdallāh ibn al-'Arabī, Ahkām al-Qur'ān, ed. 'Alī Muhammad al-Bajāwī, Cairo, 1957, on Q 5:5. For another example of Ibn al-'Arabī’s permissive attitude toward restrictions associated with Christians, see J.D. McAuliffe, 'Legal exegesis: Christians as a case study', in L. Ridgeon (ed.), Islamic interpretations of Christianity, New York, 2001, pp. 67-69. With the exception of jurists from Andalusia and North Africa, Ibn al-'Arabī among them, Muslim authorities generally assume that Christian slaughter practices conform to those of Muslim butchers. Judging by the laws found in the Nomocanon of the Syrian Orthodox Gregory Barhebraeus (d. 1286) (ed. P. Bedjan, Paris, 1898, pp. 458-67), this assumption appears to be accurate. 